\title{
PERAN HUTAN MANGROVE SEBAGAI BIOFILTER DALAM PENGENDALIAN POLUTAN Pb DAN CU DI HUTAN MANGROVE SUNGAI DONAN, CILACAP, JAWA TENGAH
}

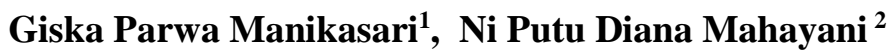 \\ ${ }^{l}$ Departemen Teknologi Hayati dan Veteriner, Sekolah Vokasi UGM \\ Email: ${ }^{1}$ giska.parwa.m@mail.ugm.ac.id \\ ${ }^{2}$ Departemen Konservasi Sumberdaya Hutan, Fakultas Kehutanan UGM \\ Email: 2dianamahayani@yahoo.com
}

\begin{abstract}
Cilacap Oil Refinery that produces heavy metal waste containing $\mathrm{Pb}$ and $\mathrm{Cu}$ is located across to the mangrove forests along Donan river banks. This study aimed to recognize the role of mangrove forest as biofilters in controlling water pollutants of $\mathrm{Pb}$ and $\mathrm{Cu}$ that is predicted containing the mangrove rehabilitation areas along Donan River banks, Cilacap. The research site was grouped into four areas, which are control zone (three km before the point source), Inner Zone (at the point source), middle zone (one $\mathrm{km}$ point source), and outer zone (estuarine). Four plots were established to measure chemical water quality and mangrove tree density. Data colected were then analyzed using regression model to identify the relationship between mangrove tree density and $\mathrm{Pb}$ and $\mathrm{Cu}$ concentration in the water, substrate, roots, and leaves of Rhizophora apiculata. Analysis of variance were applied among four zones to find out the role of mangrove as biofilters for those heavy metals. The results showed that even though $\mathrm{Pb}$ and $\mathrm{Cu}$ concentration in the water was not significantly different, however, the concentrations of those heavy metals from the point source to the estuarine zones decreased, especially the concentration of $\mathrm{Pb}$ in the substrat highly reduced. Finally, the role of mangrove forest as biofilter was also recognized from the concentration of $\mathrm{Pb}$ and $\mathrm{Cu}$ detected in the roots and leaves of Rhizophora apiculata.
\end{abstract}

Keywords: mangrove, Rhizophora apiculata, biofilter, $\mathrm{Pb}, \mathrm{Cu}$, Sungai Donan.

\section{PENDAHULUAN}

Hutan mangrove merupakan salah satu tipe ekosistem hutan yang hidup pada peralihan antara daratan dan lautan yang keberadaannya dipengaruhi oleh pergerakan ombak yang relatif kecil, berlumpur, dan adanya pasang surut air laut. Sebagai bagian dari ekosistem darat dan laut, hutan mangrove mampu berfungsi ganda, yaitu sebagai pelindung dan juga sebagai pendukung kedua ekosistem tersebut (Arief, 2003). Bagi ekosistem darat, hutan mangrove mampu melindungi pantai dari kemungkinan terjadinya abrasi, erosi, gelombang pasang, dan angin topan, sedangkan bagi ekosistem laut, hutan mangrove mempunyai arti penting karena mampu memberikan sumbangan bahan organik yang akan menunjang biota akuatik. Hal tersebut dapat dilihat dari adanya seresah yang berasal dari luruhan daun, ranting, dan bunga mangrove yang oleh mikroorganisme dan makroorganisme akan diuraikan menjadi partikelpartikel detritus yang merupakan sumber makanan penting bagi biota laut seperti plankton, 
udang, kepiting, ikan kecil, dan lain-lain. Hutan mangrove juga merupakan ekosistem utama pendukung kehidupan penting wilayah pesisir dan lautan. Demikian pula dijelaskan oleh Arief (2003), salah satu fungsi fisik dan kimia ekosistem mangrove adalah pengolah bahan limbah. Dikatakan demikian karena hutan mangrove mempunyai kemampuan untuk mengakumulasi logam-logam berat yang terdapat dalam ekosistem perairan. Fachrul (2012) juga menyatakan bahwa pada saat berbahaya mangrove berfungsi menyaring pencemaran logam berat dari daratan sebelum masuk ke lautan.

Tumbuhan mangrove dapat digunakan sebagai indikator untuk mendeteksi pencemaran logam berat yang terjadi di dalam ekosistem mangrove maupun ekosistem sekitarnya (Brooks, 1992 dalam Supriyandono, 1999). Berdasarkan fungsi akumulasi, tumbuhan mampu mengantisipasi perubahan lingkungan dengan mengadakan respon tertentu apabila terdapat ion toksis. Ketahanan tumbuhan terhadap pengaruh toksisitas dilakukan dengan mekanisme penghindaran fenologis, eksklusi, ameliorasi, dan toleransi (Fitter dan Hay, 1991).

Lokasi penelitian ini dilaksanakan di kawasan rehabilitasi Hutan Mangrove Segara Anakan, tepatnya di tepi Sungai Donan, Cilacap, Jawa Tengah. Kawasan Pantai Cilacap merupakan muara dari sungai-sungai yang dijadikan tempat pembuangan limbah. Kawasan ini dikembangkan sebagai kawasan industri tempat dibangun berbagai industri dan beberapa diantaranya terletak di tepi Sungai Donan dan membuang limbahnya ke perairan sungai tersebut (Sugiharto, 2005). Berdasarkan hasil penelitian mengenai kualitas perairan di daerah Cilacap pada tahun 1984 oleh Bachtiar dan Prasetyo (1984) dalam dalam Perdana (2006), keberadaan logam berat di perairan Cilacap sejak tahun 1977 sampai akhir 1983 tidak mengalami perubahan yang mencolok. Namun demikian, sejak tahun 1980 dapat dikatakan bahwa kandungan logam berat dan minyak di dalam perairan Sungai Donan telah melampaui nilai ambang batas yang ditentukan. Dalam penelitian tersebut juga disebutkan adanya kecenderungan kenaikan logam berat pada sedimen dari tahun ke tahun yang berkaitan erat dengan kegiatan industri di sekitar Sungai Donan terutama kegiatan Kilang Minyak Cilacap. Hasil penelitian lainnya, yaitu berdasarkan hasil pemantauan kualitas air yang dilakukan pada tahun 1988 sampai 2000 menunjukkan bahwa pencemaran sudah terjadi di Sungai Donan (Hardjosuwarno, 1988 dalam Soedradjad, 2000). Pencemaran tersebut apabila tidak langsung ditangani, dalam jangka panjang Sungai Donan dapat mengalami pencemaran yang kronis sebab proses fisik (pengadukan, pengenceran, dan pengendapan) yang terjadi akan mempengaruhi kualitas air dari suatu waktu ke waktu yang lain (Guzman dkk., 1991 dalam Soedradjad, 2003). 
Giska Parwa Manikasari, Ni Putu Diana Mahayani, The Role of Mangrove Forest as Biofilters to Control Lead $(\mathrm{Pb})$ and Copper $(\mathrm{Cu})$ Pollutants in Mangrove Rehabilitation Areas along Donan River Banks, Cilacap, Cenral Java

Ekosistem mangrove yang berada di tepi Sungai Donan dengan perakarannya yang khas memiliki potensi dalam mengakumulasi logam berat yang bersumber dari kegiatan industri di sepanjang Sungai Donan. Selain itu, lumpur di hutan mangrove memiliki kandungan bahan organik yang tinggi (Supriharyono, 2000). Connel dan Miller (1995) mengatakan bahwa semakin tinggi kandungan bahan organik, semakin tinggi kemampuannya dalam menyerap dan menetralisir bahan pencemar. Namun, ekosistem mangrove itu sendiri memiliki kemampuan yang terbatas dalam menyerap dan menetralisir bahan pencemar sehingga dapat mengancam keberadaan mangrove dan ekosistem sekitarnya yang berakibat pada kematian organisme-organisme penghuni ekosistem (Mahayani, 2005).

Berdasarkan hal tersebut diatas, keberadaan dan kondisi hutan mangrove memegang peranan penting dan strategis dalam memulihkan kerusakan lingkungan perairan melalui kemampuannya dalam mengakumulasi berbagai bahan pencemar. Oleh karena itu, penelitian tentang peranan hutan mangrove sebagai biofilter dalam pengendalian bahan pencemar lingkungan, khususnya logam berat $\mathrm{Pb}$ dan $\mathrm{Cu}$ perlu dilakukan.

\section{BAHAN DAN METODE PENELITIAN}

Lokasi penelitian terbagi menjadi empat zona pengamatan dengan tiga zona ditempatkan berdasarkan jarak dari lokasi pembuangan limbah Kilang Minyak Cilacap dengan jarak masing-masing $1 \mathrm{~km}$ (Gambar 1). Selanjutnya diberi keterangan sebagai zona dalam, merupakan zona yang paling dekat dengan Kilang Minyak Cilacap, zona tengah, dan zona luar, yaitu zona yang paling dekat dengan muara. Selain ketiga zona di atas, juga ditempatkan zona pengamatan yang berada pada lokasi sejauh $3 \mathrm{~km}$ sebelum lokasi pembuangan limbah Kilang Minyak Cilacap yang disebut dengan zona kontrol. Pada tiap zona dibuat empat plot pengamatan, plot pertama terdapat di badan air (sungai) yang disebut Plot 1, sedangkan tiga plot lain ada dalam kawasan mangrove dengan nama Plot 2, 3, dan 4. Dalam setiap plot dibuat petak ukur 5 x 5 m untuk mengidentifikasi jumlah individu dan jenis mangrove (Plot 2 hingga 4) serta menjadi lokasi pengambilan sampel air, substrat, dan organ tumbuhan mangrove untuk analisis konsentrasi polutan $\mathrm{Pb}$ dan $\mathrm{Cu}$ (Plot 1 hingga 4). 

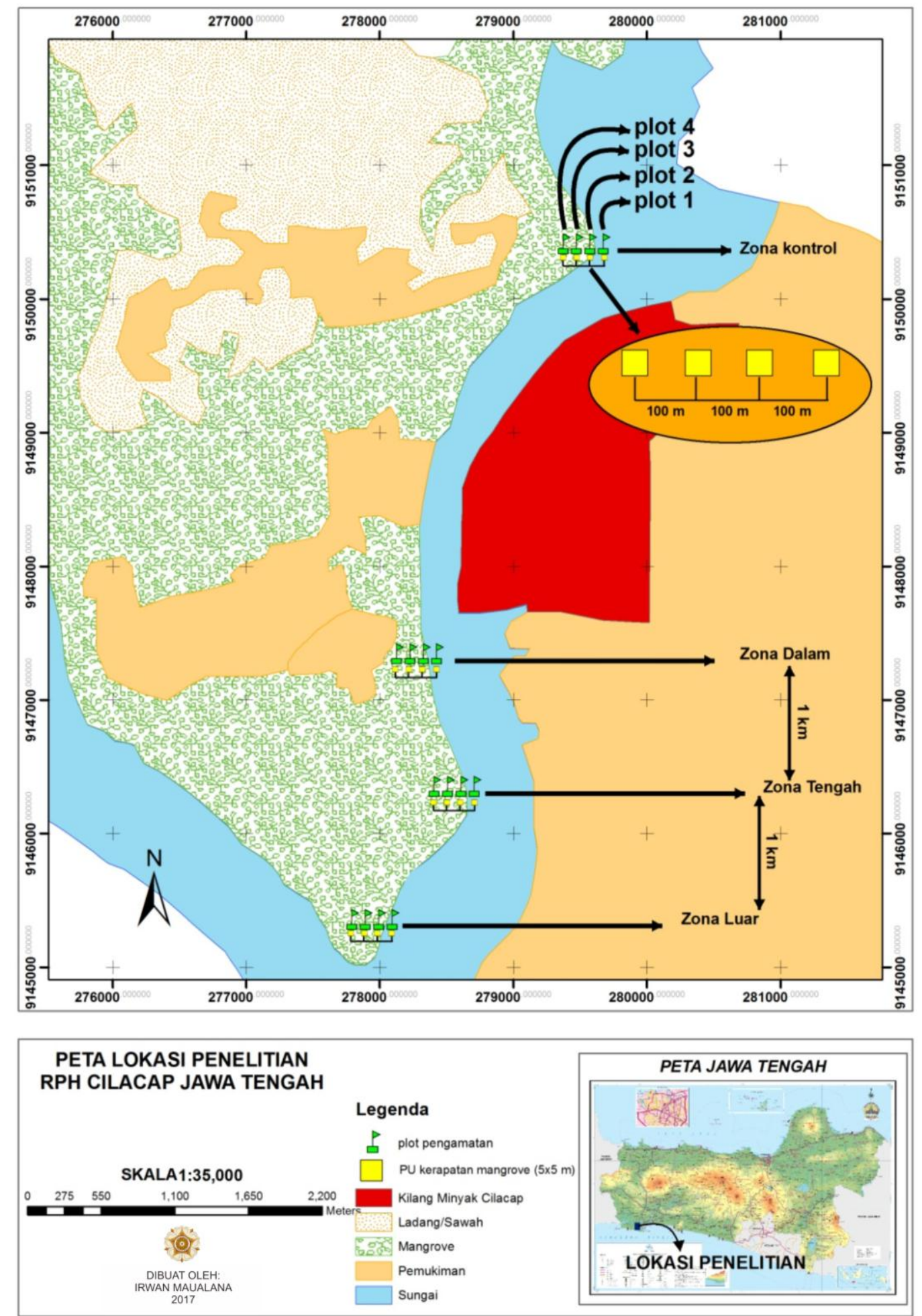

Gambar 1. Peta Lokasi Pengambilan Sampel

\section{A. Faktor biokonsentrasi (Bioconcentration Factor - BCF) dan faktor translokasi (Translocation Factor-TF)}

Setelah kandungan logam berat dalam air dan substrat serta organ tumbuhan diketahui, maka data tersebut digunakan untuk menghitung kemampuan Rhizophora apiculata dalam menyerap logam berat $\mathrm{Pb}$ dan $\mathrm{Cu}$ dari lingkungan melalui tingkat Bioconcentration Factor 
(BCF). Faktor terpenting kedua untuk melihat potensi tanaman sebagai fitoremidiator adalah nilai Translocation Factor (TF). Nilai TF menunjukkan kemampuan tanaman dalam memindahkan logam dari akar ke tajuk (Wei et al., 2008). Dari nilai BCF dapat diketahui kemampuan tumbuhan yang diteliti dalam mengakumulasi logam berat di lingkungannya, sedangkan dari nilai TF dapat diketahui proses yang dilakukan tanaman dalam mengurangi keberadaan logam merupakan proses fitoekstraksi atau fitostabilisasi.

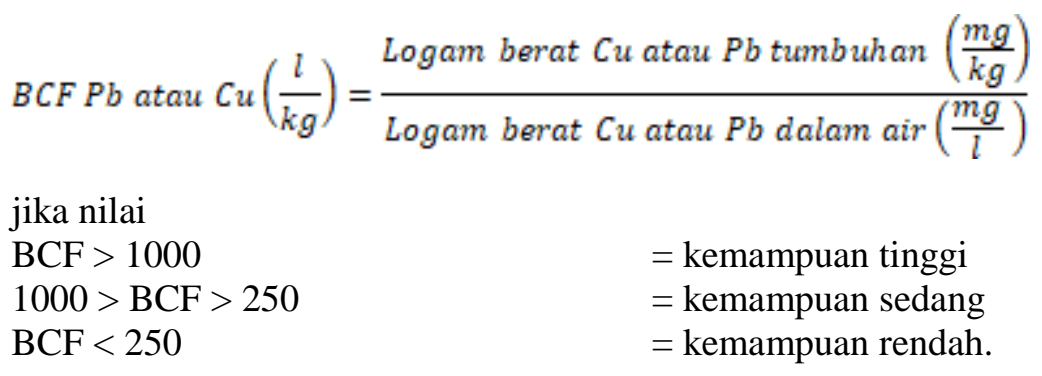

$$
\text { TF } P b \text { atau } C u=\frac{\text { Logam berat Cuatau } P b \text { daun }\left(\frac{\mathrm{mg}}{\mathrm{kg}}\right)}{\text { Logam berat } C u \text { atau } P b \text { dalam akar }\left(\frac{\mathrm{mg}}{\mathrm{kg}}\right)}
$$

Jika nilai

$\mathrm{TF}<1 \quad=$ Mekanisme fitostabilisasi

$\mathrm{TF}>1 \quad$ = Mekanisme fitoekstraksi.

\section{B. Pengaruh kerapatan absolut vegetasi mangrove terhadap konsentrasi polutan $\mathbf{P b}$ dan $\mathrm{Cu}$}

Untuk mengetahui pengaruh kerapatan absolut vegetasi mangrove terhadap konsentrasi polutan $\mathrm{Pb}$ dan $\mathrm{Cu}$ dalam air, substrat, serta organ tumbuhan (akar dan daun), dilakukan delapan analisis regresi dengan menggunakan software SPSS (Stastistical Product and Service Solutions) 17.0 for Windows dengan jumlah sampel sebanyak 16 sampel. Karena uji normalitas, uji homogenitas, dan uji linieritas sebagai asumsi analisis regresi terpenuhi, serta dengan hanya memiliki satu variabel prediktor, maka analisis yang digunakan adalah analisis regresi linear sederhana. Persamaan analisis regresi sederhana, yaitu

$$
\mathrm{Yi}=\beta 0+\beta 1 \mathrm{X}
$$

dengan keterangan sebagai berikut.

1) Variabel respon (variable dependent), yaitu variabel yang keberadaannya dipengaruhi oleh variabel lainnya dan dinotasikan dengan Yi.

2) Variabel prediktor (variable independent), yaitu variabel yang bebas tidak dipengaruhi oleh variabel lainnya dan dinotasikan dengan $\mathrm{X}$.

3) $\beta 0$, yaitu konstanta. 
4) $\beta 1$, yaitu koefisien regresi dengan masing-masing persamaan sebagai berikut.

Konsentrasi Polutan $\mathrm{Pb}$ dalam air $=\beta 0+\beta 1$ Kerapatan absolut vegetasi mangrove

Konsentrasi Polutan $\mathrm{Pb}$ dalam substrat $=\beta 0+\beta 1$ Kerapatan absolut vegetasi mangrove

Konsentrasi Polutan $\mathrm{Pb}$ dalam akar $=\beta 0+\beta 1$ Kerapatan absolut vegetasi mangrove

Konsentrasi Polutan $\mathrm{Pb}$ dalam daun $=\beta 0+\beta 1$ Kerapatan absolut vegetasi mangrove

Konsentrasi Polutan $\mathrm{Cu}$ dalam air $=\beta 0+\beta 1$ Kerapatan absolut vegetasi mangrove

Konsentrasi Polutan $\mathrm{Cu}$ dalam substrat $=\beta 0+\beta 1$ Kerapatan absolut vegetasi mangrove

Konsentrasi Polutan $\mathrm{Cu}$ dalam akar $=\beta 0+\beta 1$ Kerapatan absolut vegetasi mangrove

Konsentrasi Polutan $\mathrm{Cu}$ dalam daun $=\beta 0+\beta 1$ Kerapatan absolut vegetasi mangrove .

\section{Perbedaan konsentrasi polutan $\mathrm{Pb}$ dan $\mathrm{Cu}$ di keempat zona pengamatan}

Data konsentrasi polutan $\mathrm{Pb}$ dan $\mathrm{Cu}$ dalam air dan substrat dengan jumlah sampel masing-masing 16 sampel (satu kali ulangan) dengan empat perlakuan berupa zona pengamatan dengan unit eksperimen berupa plot pengamatan kemudian dianalisis secara statistik dengan menggunakan uji One way Anova (Analysis of Variance) atau analisis sidik ragam satu faktor untuk mengetahui perbedaan konsentrasi polutan $\mathrm{Pb}$ dan $\mathrm{Cu}$ pada tiap zona pengamatan. Analisis sidik ragam satu faktor digunakan karena hanya memperhitungkan satu faktor yang menimbulkan variansi, yaitu zona pengamatan, serta terpenuhinya uji normalitas dan uji kesamaan variansi. Untuk mengetahui secara lebih detail bagian yang berbeda, digunakan uji lanjut Least Significant Difference ( $L S D)$ atau disebut uji lanjut Beda Nyata Terkecil (BNT) karena asumsi kesamaan variansi telah terpenuhi dan jumlah sampel tiap variabel adalah sama. Pengujian BNT dilakukan berdasarkan dua nilai baku $(\alpha)$ pembanding terhadap perbedaan rata-rata, yaitu $\operatorname{LSD}(\alpha=5 \%)$ dan $\operatorname{LSD}(\alpha=1 \%)$, yang diperoleh dengan mengalikan nilai t-sudent dengan nilai galat baku rerata deviasi (S $\delta$ ).

\section{HASIL DAN PEMBAHASAN}

Faktor Biokonsentrasi (Bioconcentration Factor - BCF) dan Faktor Translokasi (Translocation Factor TF) Logam Pb dan Cu

Akumulasi logam bisa dilihat dengan cara membandingkan konsentrasi antar organ tumbuhan mangrove. Baker dan Brooks (1989) dalam Hamzah dan Setiawan (2010) menyatakan bahwa tumbuhan mampu mengakumulasi logam berat hingga $>1000 \mathrm{mg} / \mathrm{kg}$ dan dikenal sebagai hiperakumulator. Bioconcentration factors (BCF) dan Translocation factors (TF) bisa digunakan untuk menduga tumbuhan yang bisa dijadikan sebagai fitoremediasi. Melalui hasil analisis konsentrasi polutan $\mathrm{Pb}$ dan $\mathrm{Cu}$ pada masing-masing zona maka dapat dihitung nilai BCF untuk melihat sejauh mana Rhizophora apiculata mampu mengakumulasi 
polutan tersebut dalam air dengan kata lain untuk mengetahui seberapa besar konsentrasi logam pada daun dan akar yang berasal dari lingkungan (MacFarlane et al., 2003), sedangkan dari nilai TF dapat diketahui proses yang dilakukan Rhizophora apiculata dalam mengurangi keberadaan logam apakah merupakan proses fitoekstraksi atau fitostabilisasi.

Tabel 1. Nilai Faktor Biokonsentrasi (BCF) Pb dan Cu di Keempat Zona Pengamatan

\begin{tabular}{lllllll}
\hline \multicolumn{1}{c}{ Zona } & $\begin{array}{c}\text { Konsentrasi Pb } \\
\text { Tumbuhan } \\
\left(\begin{array}{c}\text { Akardan Daun }) \\
(\mathrm{mg} / \mathrm{kg})\end{array}\right.\end{array}$ & Air $(\mathrm{mg} / \mathrm{l})$ & $\begin{array}{c}\mathrm{BCF} \mathrm{Pb} \\
(\mathrm{l} / \mathrm{kg})\end{array}$ & $\begin{array}{c}\text { Konsentrasi Cu } \\
\text { Tumbuhan } \\
(\text { Akar dan daun) } \\
(\mathrm{mg} / \mathrm{kg})\end{array}$ & $\begin{array}{c}\text { Air }(\mathrm{mg} / \mathrm{l}) \\
\mathrm{BCF} \mathrm{Cu} \\
(\mathrm{l} / \mathrm{kg})\end{array}$ \\
\hline Kontrol & 2.44 & 0.004 & 668.95 & 4.67 & 0.017 & 274.44 \\
Dalam & 4.35 & 0.015 & 297.64 & 7.96 & 0.04 & 198.29 \\
Tengah & 1.66 & 0.004 & 455.25 & 5.49 & 0.022 & 251.21 \\
Luar & 2.02 & 0.007 & 276.33 & 5.58 & 0.023 & 241.18 \\
\hline
\end{tabular}

Tabel 2. Nilai Faktor Translokasi (TF) Pb dan Cu di Keempat Zona Pengamatan

\begin{tabular}{|c|c|c|c|c|c|c|}
\hline Zona & $\begin{array}{l}\mathrm{Pb} \text { dalam } \\
\text { Daun } \\
(\mathrm{mg} / \mathrm{kg})\end{array}$ & $\begin{array}{c}\text { Pb dalam } \\
\text { Akar }(\mathrm{mg} / \mathrm{kg})\end{array}$ & $\mathrm{TF} \mathrm{Pb}$ & $\begin{array}{c}\text { Cu dalam } \\
\text { Daun }(\mathrm{mg} / \mathrm{kg})\end{array}$ & $\begin{array}{c}\mathrm{Cu} \text { dalam } \\
\text { Akar } \\
(\mathrm{mg} / \mathrm{kg})\end{array}$ & $\mathrm{TF} \mathrm{Cu}$ \\
\hline Kontrol & 0.384 & 2.06 & 0.19 & 2.22 & 2.44 & 0.91 \\
\hline Dalam & 0.855 & 3.49 & 0.24 & 3.58 & 4.38 & 0.82 \\
\hline Tengah & 0.156 & 1.51 & 0.10 & 2.47 & 3.02 & 0.82 \\
\hline Luar & 0.170 & 1.85 & 0.09 & 2.54 & 3.03 & 0.84 \\
\hline
\end{tabular}

Berdasarkan hasil perhitungan nilai Faktor Biokonsentrasi (BCF) dalam air diketahui nilai BCF Cu Zona Kontrol sebesar 274,44 1/kg dan Zona Tengah sebesar 251, 21 1/kg dikategorikan memiliki kemampuan sedang sementara Zona Dalam dan Zona Luar termasuk dalam kategoti rendah karena nilai BCF Cu lebih kecil dari 250 1/kg. Sementara itu, nilai $\mathrm{BCF} \mathrm{Pb}$ termasuk dalam kategori sedang untuk semua zona. Nilai BCF tertinggi sebesar 668,95 (Pb) dan terendah 198,29 (Cu) sehingga dapat ditarik kesimpulan bahwa kemampuan Rhizophora apiculata dalam mengakumulasi logam berat dalam air berupa $\mathrm{Pb}$ lebih besar daripada logam $\mathrm{Cu}$.

Data BCF tersebut menunjukkan bahwa pohon Rhizophora apiculata mempunyai kecenderungan untuk menyerap dan mengakumulasi logam berat yang terdapat dalam ekosistem habitatnya. Perbedaan konsentrasi logam berat pada organ tumbuhan tertentu berkaitan dengan proses fisiologis tumbuhan tersebut. Menurut Rosmarkam dan Nasih (2002) bahwa ada tiga jalan yang dapat ditempuh oleh air dan ion-ion yang terlarut bergerak menuju sel-sel xylem dalam akar, yaitu (1) melalui dinding sel (apoplas) epidermis dan sel-sel korteks, (2) melalui sistem sitoplasma (simplas) yang bergerak dari sel ke sel, dan (3) melalui sel hidup pada akar, dimana sitosol dari setiap sel membentuk suatu jalur. 
Brooks (1997) dalam Hamzah dan Setiawan (2010) mengatakan akumulasi logam ke dalam akar tumbuhan melalui bantuan transpor molekul dalam membran akar kemudian akan membentuk transpor logam kompleks yang menembus xilem dan terus menuju sel daun. Setelah sampai di daun, logam akan melewati plasmalemma, sitoplasma, dan tonoplasma untuk memasuki vakuola. Di dalam vakuola transpor, molekul kompleks bereaksi dengan akseptor terminal molekul untuk membentuk akseptor kompleks logam kemudian transpor molekul dilepas dan akseptor kompleks logam terakumulasi dalam vakuola yang tidak akan berhubungan dengan proses fisiologi sel tumbuhan.

Kapasitas transfer logam dari akar ke daun dihitung dengan menggunakan perhitungan faktor translokasi (Translocation Factor-TF). Hasil penelitian menunjukkan bahwa nilai TF dari akar ke daun bervariasi antara 0,09-0,91. Menurut sifatnya, logam berat Pb merupakan logam yang memiliki daya translokasi yang rendah (Hamzah dan Setiawan, 2010) sehingga nilai $\mathrm{TF} \mathrm{Pb}$ lebih kecil dari $\mathrm{Cu}$ yang biasanya mengalami translokasi pembentukan khelat dengan asam-asam poliamino-polikarboksilik. Dengan kata lain, logam $\mathrm{Pb}$ lebih lambat ditranslokasikan ke tajuk dibandingkan dengan logam $\mathrm{Cu}$. Hasil ini juga menunjukkan bahwa Rhizophora apiculata bukanlah tumbuhan hiperakumulator sebab untuk menjadi tumbuhan hiperakumulator, besar faktor translokasi harus lebih dari satu (TF > 1) (Lorestani et al., 2011 dalam Siahaan et al., 2013). Tumbuhan hiperakumulator adalah tumbuhan yang dapat mengakumulasi logam dengan konsentrasi yang sangat tinggi pada jaringan permukaan (aboveground) di habitat alamiahnya (Baker dan Brooks, 1989). Nilai TF < 1 menunjukkan Rhizophora apiculata pada hutan mangrove di tepi Sungai Donan mengalami mekanisme fitostabilisasi. Fitostabilisasi adalah penghentian kontaminan di tanah melalui absorpsi dan akumulasi oleh akar. Fitostabilisasi sangat berguna untuk pengolahan timbal, arsenik, cadmium, kromium, tembaga, dan seng. Hal tersebut menunjukkan bahwa Rhizophora apiculata akan menghambat mobilitas logam dalam sedimen dan terbawa aliran air.

\section{Pengaruh Kerapatan Absolut Vegetasi Terhadap Konsentrasi Logam Berat}

\section{Tabel 3. Hasil Analisis Regresi untuk Variabel Kerapatan Absolut Vegetasi Mangrove}

\begin{tabular}{|c|c|c|c|c|c|}
\hline \multicolumn{3}{|c|}{ Variabel } & \multicolumn{3}{|c|}{ Hasil Analisis Regresi } \\
\hline $\mathrm{Xi}$ & & $\mathrm{Yi}$ & $\begin{array}{c}\text { Koefisien } \\
\text { Determinasi }\end{array}$ & Signifikansi & Persamaan \\
\hline \multirow{7}{*}{$\begin{array}{l}\text { Kerapatan } \\
\text { absolut } \\
\text { vegetasi } \\
\text { mangrove }\end{array}$} & \multirow{4}{*}{$\begin{array}{l}\text { Kosentrasi } \\
\mathrm{Pb}\end{array}$} & dalam air & 0,615 & 0,002 & $Y i=1,078^{*} 10^{-6} \mathrm{Xi}$ \\
\hline & & dalam sedimen & 0,847 & 0,000 & $Y i=0,001 X i$ \\
\hline & & dalam daun & 0,476 & 0,013 & $Y i=1,444+X i$ \\
\hline & & dalam akar & 0,729 & 0,000 & $Y i=1,419 * 10^{-5} X i$ \\
\hline & \multirow{3}{*}{$\begin{array}{l}\text { Kosentrasi } \\
\mathrm{Cu}\end{array}$} & dalam air & 0,798 & 0,000 & $Y i=3,300 * 10^{-6} X i$ \\
\hline & & dalam sedimen & 0,843 & 0,000 & $Y i=0,001 X i$ \\
\hline & & dalam daun & 0,899 & 0,000 & $Y i=X i$ \\
\hline
\end{tabular}




\begin{tabular}{ccccc}
\hline & Variabel & \multicolumn{2}{c}{ Hasil Analisis Regresi } \\
Xi & Yi & Koefisien & Signifikansi & Persamaan \\
\hline & dalam akar & 0,918 & 0,000 & $Y i=2,023^{*} 10^{-5} \mathrm{Xi}$ \\
\hline
\end{tabular}

Tabel di atas memberikan informasi tentang model persamaan regresi yang diperoleh serta signifikansi dari koefisien regresi. Hal ini dapat dilihat dari nilai signifikansi yang diperoleh. Nilai signifikansi dari variabel bebas (kerapatan absolut vegetasi mangrove) lebih kecil dari 0,05 sehingga dapat disimpulkan bahwa pengaruh variabel bebas tersebut signifikan atau terdapat pengaruh kerapatan absolut vegetasi mangrove terhadap konsentrasi logam berat baik $\mathrm{Pb}$ maupun $\mathrm{Cu}$ dalam air, substrat, serta organ tumbuhan berupa akar dan daun. Nilai koefisien determinasi menyatakan besarnya kontribusi variabel X (kerapatan absolut vegetasi mangrove) terhadap perubahan variabel $\mathrm{Yi}$ (Konsentrasi polutan $\mathrm{Pb}$ dan $\mathrm{Cu}$ ). Nilai koefisien determinasi pada Tabel 3 tidak ada yang menunjukkan nilai 1, berarti ada variabel lain selain kerapatan absolut vegetasi mangrove yang memengaruhi konsentrasi polutan $\mathrm{Pb}$ dan $\mathrm{Cu}$ di kawasan tersebut.

Pengaruh kerapatan absolut vegetasi mangrove terhadap konsentrasi logam $\mathrm{Pb}$ dan $\mathrm{Cu}$ di perairan menunjukkan nilai koefisien positif. Hal tersebut berarti semakin tinggi nilai kerapatan absolut vegetasi mangrove semakin tinggi pula konsentrasi logam berat dalam perairan. Sebagai contoh salah satu persamaan di bawah ini.

Konsentrasi $\mathrm{Pb}$ dalam air $=1,079 * 10^{-6}$ kerapatan absolut vegetasi mangrove.

Persamaan di atas memiliki arti pada tiap kenaikan 1 pohon/ha menyebabkan kenaikan konsentrasi $\mathrm{Pb}$ dalam air yang terperangkap dalam kawasan mangrove sebesar $1,079 \times 10^{-6}$ $\mathrm{mg} / \mathrm{l}$. Hal tersebut terkait dengan keberadaan ekosistem mangrove di suatu kawasan, ekosistem mangrove selain mampu menahan sedimen juga mampu menahan air yang memasuki kawasannya. Semakin rapat kawasan mangrove semakin banyak pula air yang terperangkap dalam kawasan tersebut. Air yang terperangkap adalah air permukaan bagian bawah, bentuk logam berat yang berupa partikel meyebabkan logam berat berada pada bagian tersebut sehingga semakin rapat suatu kawasan, semakin banyak pula kandungan logam berat dalam air di kawasan tersebut. Berdasarkan hal tersebut, dapat dikatakan bahwa mangrove di tepi Sungai Donan berperan dalam mengurangi konsentrasi logam berat dalam air yang keluar dari kawasan tersebut.

Pengaruh kerapatan absolut vegetasi mangrove terhadap konsentrasi $\mathrm{Pb}$ dan $\mathrm{Cu}$ dalam sedimen juga menunjukkan nilai koefisien positif atau dapat dikatakan bahwa semakin tinggi 
kerapatan absolut vegetasi mangrove semakin tinggi pula konsentrasi polutan $\mathrm{Pb}$ dan $\mathrm{Cu}$ dalam sedimen di kawasan tersebut. Hal tersebut berkaitan dengan kemampuan akar mangrove dalam mengikat sedimen. Jadi, semakin banyak individu dalam suatu kawasan semakin banyak pula sedimen yang terikat oleh akar mangrove. Jika kawasan tersebut tercemar oleh logam berat $\mathrm{Pb}$ atau $\mathrm{Cu}$, dalam sedimen tersebut akan terkandung logam berat $\mathrm{Pb}$ atau $\mathrm{Cu}$ karena bentuk $\mathrm{Pb}$ dan $\mathrm{Cu}$ yang berupa partikel mempercepat logam tersebut terakumulasi dalam sedimen. Nybakken (1982) dalam Marasabessy dkk (2009) menjelaskan bahwa sekali mengendap sedimen tidak akan dialirkan lagi keluar. Hal ini menunjukkan bahwa sedimen (mengandung logam berat) yang terbawa aliran akan tertahan pada perakaran mangrove sehingga semakin lama sedimen yang terbawa aliran akan berkurang dari lokasi satu ke lokasi lain sepanjang aliran sungai. Berdasarkan hal tersebut, ekosistem mangrove terbukti mampu mengurangi konsentrasi polutan $\mathrm{Pb}$ dan $\mathrm{Cu}$ yang keluar dari kawasan tersebut.

Pengaruh kerapatan absolut vegetasi mangrove terhadap konsentrasi $\mathrm{Pb}$ dan $\mathrm{Cu}$ dalam organ tumbuhan (akar dan daun) menunjukkan nilai koefisien yang positif artinya terjadi hubungan positif antara kerapatan absolut vegetasi mangrove dengan konsentrasi $\mathrm{Pb}$ dan $\mathrm{Cu}$ dalam organ tumbuhan, semakin rapat mangrove di suatu kawasan maka semakin meningkatkan konsentrasi $\mathrm{Pb}$ dan $\mathrm{Cu}$ dalam organ tumbuhan. Hal tersebut terkait dengan kemampuan mangrove dalam menyerap logam berat melalui akar yang kemudian didistribusikan ke bagian tubuh yang lain seperti cabang dan daun serta melalui stomata pada daun (Wittig, 1993 dalam Munawar dan Rina, 2010).

Berdasarkan beberapa persamaan regresi di atas, dapat disimpulkan bahwa keberadaan hutan mangrove memiliki peran dalam mengurangi polutan logam berat, baik dalam skala ekosistem (penahan sedimen dan air) maupun sebagai vegetasi yang memiliki kemampuan dalam menyerap logam berat. Semakin rapat mangrove di suatu kawasan, semakin tinggi pula konsentrasi polutan yang tersimpan dalam kawasan tersebut sehingga semakin berkurang pula konsentrasi polutan yang keluar kawasan.

\section{Kemampuan Hutan Mangrove sebagai Biofilter Dalam Pengendalian Polutan Pb dan $\mathrm{Cu}$}

Kandungan logam berat yang diuji adalah logam berat timbal $(\mathrm{Pb})$ dan tembaga $(\mathrm{Cu})$ yang terdapat di air dan sedimen (lumpur). Pengukuran polutan $\mathrm{Pb}$ dan $\mathrm{Cu}$ sama halnya dengan pengukuran kualitas fisik dan kimia habitat lainnya, yaitu pada empat zona berupa Zona Kontrol, Zona Dalam, Zona Tengah, dan Zona Luar. Untuk mengetahui peran hutan 
Giska Parwa Manikasari, Ni Putu Diana Mahayani, The Role of Mangrove Forest as Biofilters to Control Lead $(\mathrm{Pb})$ and Copper $(\mathrm{Cu})$ Pollutants in Mangrove Rehabilitation Areas along Donan River Banks, Cilacap, Cenral Java

mangrove sebagai biofilter dalam pengendalian polutan $\mathrm{Pb}$ dan $\mathrm{Cu}$, analisis sidik ragam dilakukan dengan hasil berikut ini.

Tabel 4. Analisis Sidik Ragam untuk Variabel Konsentrasi Polutan Pb dan Cu dalam Air Serta Sedimen pada Tiap Zona Pengamatan

\begin{tabular}{lll}
\hline Variabel & Perlakuan & Signifikansi \\
\hline Konsentrasi Pb dalam air & & 0,310 \\
Konsentrasi Pb dalam sedimen & Antar Zona & $0,046^{*}$ \\
Konsentrasi Cu dalam air & & 0,361 \\
Konsentrasi Cu dalam sedimen & 0,493 \\
\hline
\end{tabular}

Tabel di atas menunjukkan nilai signifikansi (Sig.) masing-masing variabel polutan $\mathrm{Pb}$ dan $\mathrm{Cu}$ dalam air dan sedimen. Nilai signifikansi dari variabel polutan $\mathrm{Pb}$ dalam air serta polutan $\mathrm{Cu}$ dalam air dan sedimen lebih dari 0,05, H0 diterima, menunjukkan bahwa tidak ada perbedaan konsentrasi polutan $\mathrm{Pb}$ dalam air maupun konsentrasi polutan $\mathrm{Cu}$ dalam air dan sedimen di antara ke empat zona pengamatan. Sementara itu, konsentrasi logam $\mathrm{Pb}$ dalam sedimen menunjukkan nilai signifikansi 0,046 yang lebih kecil dibandingkan dengan nilai tingkat signifikansi 5\% $(0,05)$ berarti ada perbedaan konsentrasi $\mathrm{Pb}$ dalam sedimen yang signifikan diantara ke empat zona tersebut. Selanjutnya, dilakukan analisis pembandingan ganda untuk melihat zona mana saja yang berbeda dan zona mana saja yang relatif sama dengan uji lanjut BNT (Beda Nyata Terkecil). Uji lanjut BNT dipilih karena setiap variabel yang dianalisis telah memenuhi asumsi kesamaan variansi dimana sig. > 0,05 (terdapat variasi) serta jumlah data tiap variabel adalah sama.

Tabel 5. Hasil Uji Lanjut BNT untuk Variabel Polutan Pb dalam Sedimen Tiap Zona Pengamatan

\begin{tabular}{lll}
\hline (I) Zona & (J) Zona & Signifikansi \\
\hline \multirow{2}{*}{ Kontrol } & Dalam & $0,029^{*}$ \\
& Tengah & 0,721 \\
& Luar & 0,862 \\
Dalam & Kontrol & $0,029^{*}$ \\
& Tengah & $0,015^{*}$ \\
& Luar & $0,021^{*}$ \\
Tengah & Kontrol & 0,721 \\
& Dalam & $0,015^{*}$ \\
\multirow{2}{*}{ Luar } & Luar & 0,854 \\
& Kontrol & 0,862 \\
& Dalam & $0,021^{*}$ \\
\hline
\end{tabular}

${ }^{*}$ Berbeda signifikan pada taraf uji 0,05

Hasil uji lanjut BNT (Tabel 5) untuk perbedaan konsentrasi polutan $\mathrm{Pb}$ dalam zona menunjukkan bahwa terdapat perbedaan yang signifikan pada Zona Dalam terhadap Zona 
Tengah, Zona Luar, dan Zona Kontrol sedangkan Zona Tengah dan Zona Luar tidak memiliki perbedaan yang signifikan terhadap Zona Kontrol. Hal tersebut menunjukkan bahwa semakin menjauhi Kilang Minyak Pertama konsentrasi polutan Pb-nya semakin mendekati nilai konsentrasi $\mathrm{Pb}$ di Zona Kontrol. Dengan kata lain, keberadaan mangrove di tepi Sungai Donan mampu mengurangi polutan $\mathrm{Pb}$ melalui mekanisme pengendapan logam berat dalam lumpur.

Di sisi lain, berdasarkan Tabel 4, hutan mangrove di tepi Sungai Donan, Cilacap belum mampu mengurangi konsentrasi polutan $\mathrm{Pb}$ dalam air serta polutan $\mathrm{Cu}$ dalam air dan sedimen secara signifikan. Hal tersebut menunjukkan bahwa peranan hutan mangrove di tepi Sungai Donan sebagai biofilter tidak berfungsi maksimal. Walaupun konsentrasi polutan $\mathrm{Cu}$ dalam sedimen masih di bawah baku mutu yang ditetapkan, tetapi ketidakmampuan ekosistem mangrove dalam meminimalisir konsentrasi polutan $\mathrm{Cu}$ dalam sedimen secara signifikan lama kelamaan dapat menyebabkan perubahan status cemar air menjadi lebih tinggi.

\section{KESIMPULAN}

Peranan hutan mangrove sebagai biofilter dalam pengendalian polutan $\mathrm{Pb}$ dan $\mathrm{Cu}$ di perairan mangrove di tepi Sungai Donan, Cilacap dapat disimpulkan bahwa Hutan mangrove di tepi Sungai Donan berperan dalam mengurangi konsentrasi polutan $\mathrm{Pb}$ dalam air dan substrat dari sumber polutan keluaran terutama konsentrasi polutan $\mathrm{Pb}$ dalam substrat yang berkurang secara signifikan. Hutan mangrove di tepi Sungai Donan juga berperan dalam mengurangi konsentrasi polutan $\mathrm{Cu}$ dalam air dan substrat dari sumber polutan ke luaran walaupun tidak berbeda signifikan. Kemampuan mangrove sebagai biofilter juga dibuktikan dengan terdapatnya kandungan $\mathrm{Pb}$ dan $\mathrm{Cu}$ dalam organ tumbuhan Rhizophora apiculata baik akar maupun daun yang terdapat pada kawasan tersebut.

\section{DAFTAR PUSTAKA}

Arief, A. (2003). Hutan Mangrove Fungsi dan Manfaatnya. Yogyakarta: Kanisius.

Baker AJM, Brooks RR. (1989). Terrestrial higher plants which hyperaccumulate metal elements- a reveiew of their distribution, ecology and phytochemistry. Biorecovery 1:81-126.

Connel, D.W. dan Greg M. (1995). Kimiawi dan Ekotoksikologi Pencemaran. Jakarta: UI Press.

Fachrul, M.F. (2012). Metode Sampling Bioekologi (Cetakan Ketiga). Jakarta: Bumi Aksara.

Fitter, A.H., dan Hay R.K. (1991). Fisiologi Lingkungan Tanaman. Yogyakarta: Gadjah Mada University Press. 
Hamzah, F dan Agus, S. (2010). Akumulasi Logam Berat Pb, Cu, dan Zn di Hutan Mangrove Muara Angke, Jakarta Utara. Jurnal Ilmu dan Teknologi Kelautan Tropis. Vol. 2 (2): 41-52

Macfarlane, G.R., Pulkownik, A., Burchett M.D. (2003). Accumulation and distribution of heavy metal in grey mangrove, Avicennia marina (Forsk) VierhBiological Indication Potential. Journal of Environmental Pollution (123): 139.

Mahayani, N.P.D. (2005). Kemampuan Hutan Mangrove sebagai Biofilter Terhadap Pencemaran Lingkungan (Studi Kasus di Hutan Mangrove Ngurah Rai Prapat Benoa, Bali). Yogyakarta: Departemen Pendidikan dan Kebudayaan Universitas Gadjah Mada.

Marasabessyi, M.D., Edward., dan Febriana L.V. (2009). Pemantauan Konsentrasi Logam Berat dalam Air Laut dan Sedimen di Perairan Pulau Bacan, Maluku Utara. Makara Sains. Vol 14: 32-38.

Munawar, A dan Rina. (2010). Kemampuan Tanaman Mangrove untuk Menyerap Logam Berat Merkuri $(\mathrm{Hg})$ dan Timbal $(\mathrm{Pb})$. Dalam: www.scholar.google.co.id/Accessed 18.04. 17

Perdana, A.D. (2006). Pengenalan Tipe-Tipe Hutan. Dalam: www.adhisuryaperdana.wordpress.com/ Accessed 18.04. 17

Rosmakam, A dan Nasih W. Y. (2002). Ilmu Kesuburan Tanah. Yogyakarta: Kanisius.

Siahaan, M. T. A., Ambariyanto, Bambang Y. (2013). Pengaruh Pemberian Timbal (Pb) dengan Konsentrasi Berbeda terhadap Klorofil, Kandungan Timbal pada Akar dan Daun, serta Struktur Histologi Jaringan Akar Anakan Mangrove Rhizophora mucronata. Journal of Marine Research. Vol. 2 (2): 111-119.

Soedradjad, R. (2000). Konsentrasi pencemar minyak dan fenol di estuari Sungai Donan, Cilacap. Laporan penelitian Universitas Jember, Jember. 44-58.

Soedradjad, R. (2003). Fungsi Model Hidrodinamika Estuari Dalam Pengelolaan Ekosistem Mangrove (Studi Kasus Pencemaran Minyak di Estuari Sungai Donan Cilacap). Berkala Penelitian Hayati Universitas Airlangga. Vol. 8: 81-86.

Sugiharto. (2005). Analisis Keberadaan Dan Sebaran Komunitas Larva Pelagis Ikan pada Ekosistem Pelawangan Timur Segara Anakan - Cilacap (Tesis).

Supriharyono. (2000). Pelestarian dan Pengelolaan Sumberdaya Alam di Wilayah Pesisir Tropis. PT Gramedia Pustaka Utama, Jakarta.

Supriyandono. (1999). Lahan Hutan Untuk Mendaur Air Limbah Suatu Peluang yang Mengarah ke Kebutuhan Lingkungan. Buletin Kehutanan. Vol.38: 61-68.

Wei, S., Qixing Z., dan Shiny M. 2008. A newly found cadmium accumulator Taraxacum mongolicum. Journal of Hazardous Materials. 159: 544-547. 